\title{
ASSOCIATIONS BETWEEN THE CHARACTERISTICS OF LARGE NATIONAL REGIONS, INDIVIDUAL ALCOHOL CONSUMPTION AND TOBACCO SMOKING: A SYSTEMATIC REVIEW PROTOCOL
}

\author{
${ }^{1}$ S. A. Maksimov, ${ }^{2}$ D. P. Tsygankova, ${ }^{2}$ Y. V. Danilchenko, ${ }^{1}$ S. A. Shalnova, ${ }^{1}$ A. A. Zelenina, \\ ${ }^{1}$ O. M. Drapkina \\ ${ }^{1}$ National Medical Research Center for Therapy and Preventive Medicine, Moscow, Russia; \\ ${ }^{2}$ Research Institute for Complex Issues of Cardiovascular Diseases, Kemerovo, Russia
}

\begin{abstract}
Introduction: Tobacco smoking and hazardous alcohol consumption significantly contribute to the burden of diseases worldwide. Characteristics of the environment has been consistently shown to be associated with the patterns of tobacco smoking and alcohol consumption patterns. This evidence has been previously summarized on country- and neighbourhood-level reviews although the evidence on the associations on the regional level is still scarce.

Aim: to present a protocol of the systematic review of available evidence on the associations between certain characteristics of large national regions and alcohol consumption and tobacco smoking.

Methods: A systematic search of PubMed, Google Scholar, OpenGrey, CrossRef, and eLibrary) will be conducted to identify original studies with no date or language restrictions. Only studies with territorial characteristics as exposure variables and with tobacco smoking and alcohol consumption as the outcomes will be selected. The studies have no restrictions regarding participant characteristics, that is, gender, age, socioeconomic criteria, or health status. Titles, abstracts, and full text of articles retrieved from the search will be screened and read independently by two reviewers for eligibility. Articles selected for inclusion will be critically and independently appraised by two reviewers. The full-text of the selected studies will be assessed in detail, and findings and their illustrations will be extracted and aggregated. Any disagreements between the reviewers that may arise at any stage will be resolved through discussion, or mediated by a third reviewer.
\end{abstract}

Systematic review registration number: PROSPEROCRD42021234874.

Key words: alcohol, environment, health geography, national regions, smoking

\section{СВЯЗЬ ХАРАКТЕРИСТИК КРУПНЫХ НАЦИОНАЛЬНЫХ РЕГИОНОВ С ПОТРЕБЛЕНИЕМ АЛКОГОЛЯ И ТАБАКОКУРЕНИЕМ НА ИНДИВИДУАЛЬНОМ УРОВНЕ: ПРОТОКОЛ СИСТЕМАТИЧЕСКОГО ОБЗОРА}

() 2021 г. ${ }^{1}$ С. А. Максимов, ${ }^{2}$ Д. П. Цыганкова, ${ }^{2}$ Я. В. Данильченко, ${ }^{1}$ С. А. Шальнова, ${ }^{1}$ А. А. Зеленина, ${ }^{1}$ О. М. Драпкина

${ }^{1}$ Национальный медицинский исследовательский центр терапии и профилактической медицины, г. Москва, Россия; ${ }^{2}$ Научно-исследовательский институт комплексных проблем сердечно-сосудистых заболеваний, г. Кемерово, Россия

\begin{abstract}
Введение: Табакокурение и опасное употребление алкоголя широко распространены и вносят значительный вклад в глобальное бремя болезней. Условия проживания могут оказывать существенное влияние на поведение людей в отношении табакокурения и употребления алкоголя. Эти закономерности были обобщены в обзорах литературы на уровне районов и отдельных стран, однако информации о связи между характеристиками крупных национальных регионов и изучаемыми признаками по-прежнему недостаточно. Цель: представить протокол систематического обзора, призванного обобщить имеющиеся знания о связи между характеристиками крупных национальных регионов и потреблением алкоголя и табакокурением.

Методы: Запланирован систематический поиск в PubMed, Google Scholar, OpenGrey, CrossRef и eLibrary для поиска исследований, опубликованных в рецензируемых изданиях, без ограничений по дате или языку. В этом обзоре будут рассмотрены исследования, в которых территориальные характеристики представлены в качестве одного из факторных признаков, а табакокурение и потребление алкоголя - в качестве результативных признаков. Исследования будут включаться без ограничений по полу, возрасту, социально-экономическим признакам или состоянию здоровья.

Названия, аннотации и полный текст статей, полученных в результате поиска, будут проверяться и анализироваться независимо двумя рецензентами на соответствие критериям отбора. Статьи, отобранные для включения, будут критически и независимо оценены двумя рецензентами. Полный текст выбранных исследований будет детально проанализирован, а результаты подвергнуты количественному и качественному синтезу. Любые разногласия между рецензентами, которые могут возникнуть на любом этапе, будут разрешены путем обсуждения или при посредничестве третьего рецензента.
\end{abstract}

Регистрационный номер систематического обзора: PROSPERO CRD42021234874.

Ключевые слова: алкоголь, среда проживания, география здоровья, национальные регионы, курение

For citing:

Maksimov S. A., Tsygankova D. P., Danilchenko Y. V., Shalnova S. A., Zelenina A. A., Drapkina 0. M. Associations between the characteristics 
of large national regions, individual alcohol consumption and tobacco smoking: a systematic review protocol. Ekologiya cheloveka (Human Ecology). 2021, 6, pp. 58-64.

\section{Библиографическая ссылка:}

Максимов С. А., Цыганкова Д. П., Данильченко Я. В., Шальнова С. А., Зеленина А. А., Драпкина О. М. Связь характеристик крупных национальных регионов с потреблением алкоголя и табакокурением на индивидуальном уровне: протокол систематического обзора // Экология человека. 2021. № 6. С. 58-64.

\section{Introduction}

Behavioural risk factors are a collective concept that includes a significant number of the specific features of an individual's lifestyle that can potentially affect his/ her health. The most common behavioural risk factors, especially in terms of the development of chronic noncommunicable diseases and mortality, are common bad habits-first and foremost, smoking and alcohol abuse. Large international studies such as INTERHEART, INTERSTROKE, and EPIC, as well as numerous systematic reviews and meta-analyses, have revealed the significant contribution of these risk factors to the development of myocardial infarction, stroke, diabetes mellitus, oncological diseases of any localisation, and death [1, 24, 32]. These facts support the active search for preventive measures for tobacco smoking and alcohol abuse, both within personalised programs and at a population level, primarily through legislative and regulatory measures.

The development of socio-ecological concepts of human behaviour has made the 'social production of health and disease' an important component of the causal chain of the state of an individual's health, along with biological components (gender, age, genotype) and individual social characteristics (level of education, individual wealth, marital status) $[8,18]$. There is a global need in academic circles to understand how social environment, the infrastructure of living and working environments, along with social and legislative norms, have an impact on the state of human health. In accordance with the socio-ecological model [14, 27, 29], human behaviour is driven by complex and dynamic relationships between individual, social, and physical factors of the environment, and specific features of the latter, and accordingly, contribute to an individual's lifestyle and level of health. It should be noted that the living environment, in this regard, is broadly defined and includes infrastructure, socio-economic conditions, social environment, traditional, legislative, and informational aspects of human life.

Currently, the global scientific community has a large amount of epidemiological data on the influence of environmental characteristics on human health. Thus, the systematic review of studies conducted in the United States between and 1995-2014 on the dependence of health status on the characteristics of the infrastructure of the living area included 259 studies [3]. Most of the studies were published after 2003; the fastest growth rate in the literature for the entire 20 year period was observed after the mid-2000s. Five to 10 years ago the research data were mainly limited to Australia and countries in Europe and North America with a high per capita income; however, the number has increased significantly since then [7]. Most of these studies have focused on the characteristics of small territories-districts of residence, postal and registration areas, city blocks, or communities. Several conceptual systematic reviews and meta-analyses were about such studies [2, 10, 15]. On the other hand, a number of large international studies, such as the Prospective Urban and Rural Epidemiology Study (PURE) [6], as well as some systematic reviews [4] have also examined cross-country differences. Some researchers believe that the influence of living conditions on individual health can be observed in different ways and at several levels, not only macro (countries) and micro (regions and communities) levels but also certain meso levels (large regions within countries) [13, 25, 30].

Much attention has been paid to the assessment of the impact of living conditions on tobacco smoking and alcohol consumption [2, 30]. However, these studies focused on other parameters of health status, primarily within a small area or at a cross-country level. For example, one systematic review [4] included crosscountry studies on the effect of trade and investment agreements on health, including tobacco smoking. Another review [23] of primarily cross-country studies revealed that market regulation of tobacco and alcohol was likely to be effective in improving health and reducing inequalities, that is, through high taxation or restricting advertising and accessibility. In contrast, the review by Algren et al. [2] was about the effects of the specific features of small areas on tobacco smoking and alcohol consumption among other health-related outcomes.

A number of studies on tobacco smoking and alcohol consumption have also been conducted in large national areas in the United States and Canada. For example, some studies examined the impact of income inequality (Gini index) in the United States at a state level on the likelihood of smoking among people 65 years and older [5], and alcohol consumption and alcohol-related problems [12]. Another study looked at the effect of the Gini index of Canadian provinces on smoking and alcohol consumption among adolescents $12-17$ years old [26]. Two United States studies examined the effect of the tobacco and alcoholic policy environments of states on the likelihood of smoking among adults [28] and alcohol consumption among schoolchildren in grades 9-12 [31]. Interestingly, the study Cohen SA et al. [5], in addition to the impact of income inequality at the state-level, also looked at the impact at the county-level, as well as the interaction between the two. Overall, the authors concluded that the links between income inequality and health status differ according to 
the level of spatial aggregation, which casts doubt on the overwhelming evidence that income inequality is consistently associated with worsening health status.

The study in the Russia showed that the increased Industrial index (rates of production of minerals and electric power, mortality from tuberculosis, infectious diseases and external causes, proportion of people in the region working under harmful working conditions, population size of the region, and emissions into the atmosphere) in the region associates with the probability of smoking [17]. The Economic index did not show a correlation with the probability of smoking, either in terms of the total sample size or in terms of the specific characteristics of gender, age, and level of education.

A good systematic review will help systematise current knowledge and guide decision-making in public health policies and interventions to reduce inequities in population health. A preliminary search of PROSPERO, MEDLINE, the Cochrane Database of Systematic Reviews, and the JBI Database of Systematic Reviews and Implementation Reports was conducted, and no current or proposed systematic review on the topic could be identified.

The purpose of this systematic review is to summarise the available knowledge on the effect of the characteristics of large national regions on alcohol consumption and tobacco smoking. This systematic review will help policy makers and health professionals to identify possible directions for population-based prevention of bad habits as part of national strategies aimed at improving public health. Knowledge of the main territorial effectors and the peculiarities of their influence on bad habits will allow for the development of targeted legislative programmes and preventive national and regional projects to reduce the prevalence of tobacco smoking and alcohol abuse. Large territories, usually of the first administrative level (states, regions, provinces), are the most promising for this, due to relative legislative independence within the national state.

We aim to answer three questions in this systematic review: 1) What quantitative and qualitative features are typical for studies of the impact of living conditions in large national territories on tobacco smoking and alcohol consumption? 2) What are the main associations found in the course of these studies? 3) Did they include an analysis of the interaction between the characteristics of large national territories and other territorial entitiesintercountry or small territories (neighbourhoods, districts, quarters)?

\section{Methods}

The proposed systematic review will be conducted in accordance with the Joanna Briggs Institute's methodology for systematic reviews of aetiology and risk [20] and will adhere to the preferred reporting items for systematic reviews and meta-analyses (PRISMA) [16].

This review will consider studies with no restrictions on participants, including gender, age, socioeconomic criteria, and health status.

This review will consider studies that meet the following criteria for studied impact or independent variables:
1) A studied impact/independent variable should represent a characteristic(s) of a living territory from any point of view: socio-economic, medical and organisational, industrial, legislative, informational, ethnic, etc. The impact characteristics can be represented by a univariate simple index (e.g., the Gini coefficient, crime rate, per capita household consumption) and/ or a complex index (e.g., deprivation indices). Studies that provide no characteristics (e.g., only the names of regions) or that select only geographic characteristics (e.g., southern or northern regions) will be excluded from the systematic review.

2) In terms of the size of the living area, a studied impact/independent variable should refer to large national regions that usually correspond to administrative units of the first level. For example, a state in Australia, Brazil, United States, an administrative district (periphery) in Greece, a province in Argentina, Canada, China, Indonesia, land in Germany, etc. In Russia, such administrative units are designated as subjects (regions, republics, autonomous territories, etc.). When determining the administrative territories, site data will be used: https:// ru.wikipedia.org/wiki/Таблица_административных_ единиц_по_странам. The choice of administrative units of the first level must be based on the fact that the features of the living conditions caused by the regional governance and legislation are the most visible and variable within this territorial area. Exceptions are possible for certain studies and countries. For example, in studies on the United Kingdom, these can be administrative units of the second or even third level-regions and counties. Each exclusion will be made after a joint discussion with all the reviewers and the systematic reviews will include explanations regarding each such exclusion.

This review will consider studies that include the following outcomes: tobacco smoking and alcohol consumption at an individual level. Studies that consider any phenomena associated with these behavioural risk factors, such as quitting smoking and alcohol consumption, returning to bad habits, and occasional consumption, will be of interest. Tobacco smoking and alcohol consumption can be measured both quantitatively and qualitatively. Studies on children and adolescents with outcomes registered according to their parents, guardians, or teachers will also be included in this study.

This review will include analytical observational studies, including prospective and retrospective cohort studies, case-control studies, and analytical crosssectional studies. This review will also include both experimental and quasi-experimental study designs, including randomised controlled trials, non-randomized controlled trials, before and after studies, and interrupted time series studies that report on the risks associated with interventions.

Ethical approval is not required for this secondary analysis and qualitative synthesis of already collected and published data.

The search strategy will aim to locate published studies. An initial limited search of PubMed was undertaken 
to identify articles on the topic. The text words contained in the titles and abstracts of the relevant articles and the index terms used to describe these articles were used to develop a full search strategy for PubMed (Table 1). The search strategy, including all identified keywords and index terms, will be adapted for each database and/or information source included in the study. The reference list of all the included sources of evidence will be screened for additional studies.

Table 1

Search strategy for PubMed

\begin{tabular}{|c|c|c|}
\hline Search & Query & $\begin{array}{l}\text { Records } \\
\text { retrieved }\end{array}$ \\
\hline$\# 1$ & 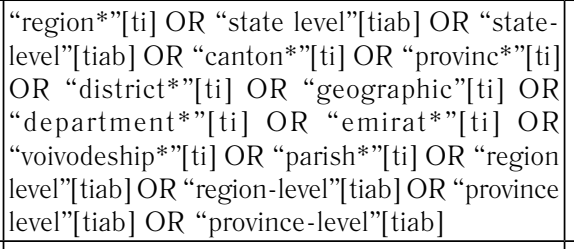 & 351,691 \\
\hline$\# 2$ & 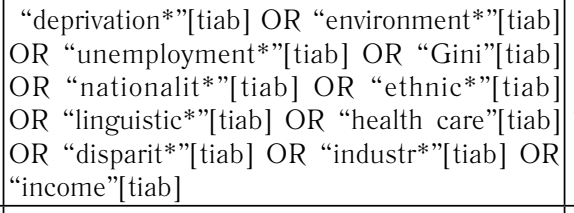 & $2,010,431$ \\
\hline \#3 & \begin{tabular}{|lll} 
“alcohol”[tiab] & OR “drink*”[tiab] & OR \\
"tobacco”[tiab] & OR “smok*”[tiab] & OR \\
"cigarette”[tiab] & &
\end{tabular} & 652,237 \\
\hline$\# 4$ & 1 AND 2 AND 3 & 2531 \\
\hline
\end{tabular}

Studies published in any language will be considered and translations will be sought where necessary. All studies published from database inception to the present will be considered.

The databases to be searched include PubMed, Google Scholar, OpenGrey, CrossRef, and eLibrary (in Russian). Studies published from database inception until 31 December 2020 will be included. The authors of articles that will be included in this systematic review will be contacted to identify additional (at the discretion of the authors) literature sources that could be suitable for the purposes of the systematic review. In addition, the following journals will be thoroughly examined: International Journal of Health Geographics (BioMed Central Ltd.) and Health and Place (Elsevier Ltd.).

\section{Study selection}

All the identified citations will be collated and uploaded into Mendeley Desktop 1.19.4 (Mendeley Ltd., Elsevier, Netherlands) and duplicates will be removed. Following a pilot test, titles and abstracts will then be screened by two independent reviewers for assessment against the inclusion criteria for the review (Table 2). Potentially relevant studies will be retrieved in full and their citation details imported into the JBI System for the Unified Management, Assessment and Review of Information (JBI SUMARI) (JBI, Adelaide, Australia) [21]. The full text of the selected citations will be assessed by two independent reviewers in detail and checked against the inclusion criteria. Reasons for the exclusion of papers (full text) that do not meet the inclusion criteria will be recorded and reported in the systematic review. Any disagreements that arise between the reviewers at every stage of the selection process will be resolved through discussion or mediated by an additional reviewer. The results of the search and the study inclusion process will be reported in full in the final systematic review and presented in a preferred reporting Items for systematic reviews and meta-analyses (PRISMA) flow diagram.

Algorithm for screening studies by titles and abstracts of articles

\begin{tabular}{c|l|l}
\hline $\begin{array}{c}\text { Num- } \\
\text { ber }\end{array}$ & \multicolumn{1}{|c}{ Question } & \multicolumn{1}{|c}{ Algorithm of responses } \\
\hline 1 & $\begin{array}{l}\text { Is the research original pri- } \\
\text { mary? }\end{array}$ & $\begin{array}{l}\text { If YES, then moving on to Q2, } \\
\text { if NO, then it is excluded }\end{array}$ \\
\hline 2 & $\begin{array}{l}\text { Is the article published in a } \\
\text { peer-reviewed journal? }\end{array}$ & $\begin{array}{l}\text { If YES, then moving on to Q3, } \\
\text { if NO, then it is excluded }\end{array}$ \\
\hline 3 & $\begin{array}{l}\text { Is the study area a large na- } \\
\text { tional region? }\end{array}$ & $\begin{array}{l}\text { If YES or not specified, then } \\
\text { moving on to Q4, if NO, then } \\
\text { it is excluded }\end{array}$ \\
\hline 4 & $\begin{array}{l}\text { Does the study present the } \\
\text { characteristics of the regions } \\
\text { at the macro level? }\end{array}$ & $\begin{array}{l}\text { If YES, then moving on to Q5, } \\
\text { if NO, then it is excluded }\end{array}$ \\
\hline 5 & $\begin{array}{l}\text { Does the study present indi- } \\
\text { vidual alcohol consumption or } \\
\text { tobacco use as results? }\end{array}$ & $\begin{array}{l}\text { If YES, then the study is in- } \\
\text { cluded }\end{array}$ \\
\hline
\end{tabular}

\section{Assessment of methodological quality}

Eligible studies will be critically appraised by two independent reviewers using the standardised critical appraisal tools incorporated within JBI SUMARI [22], as appropriate to the study designs. Authors of papers will be contacted to request missing or additional data for clarification, where required. Any disagreements that arise will be resolved through discussion or mediated with a third reviewer. The results of critical appraisal will be reported in a narrative form and summarised in a table. All the studies, regardless of the results of their methodological quality, will undergo data extraction and synthesis (where possible).

\section{Data extraction}

Data will be extracted from papers included in the review using the standardised data extraction tools in JBI SUMARI by two independent reviewers. The data extracted will include specific details about the exposure of interest, including different exposure categories if applicable, populations, study methods, and outcomes or dependent variables of significance to the review question and specific objectives (Table 3 ). Any disagreements that may arise between the reviewers will be resolved through discussion or mediated by a third reviewer. Where data are missing or insufficient, the corresponding author of the paper can be contacted up to two times via email.

\section{Data synthesis}

Papers will, where possible, be pooled in a statistical meta-analysis using JBI SUMARI. Effect sizes 
Form for extracting data from publications included in the systematic review

Table 3

\begin{tabular}{|c|c|}
\hline \multicolumn{2}{|l|}{ General information } \\
\hline Unique ID & \\
\hline \multicolumn{2}{|l|}{ Title } \\
\hline \multicolumn{2}{|l|}{ Authors } \\
\hline \multicolumn{2}{|l|}{ Journal/Source } \\
\hline \multicolumn{2}{|l|}{ Publication year } \\
\hline \multicolumn{2}{|l|}{ Extracted by (initials) } \\
\hline \multicolumn{2}{|l|}{ Design characteristics } \\
\hline \multirow{5}{*}{ - Type of study } & $\begin{array}{l}\text { Observational study: } \\
\text { prospective cohort study }\end{array}$ \\
\hline & Observational study: cross-sectional study \\
\hline & Observational study: prevalence \\
\hline & Evaluation of confounding \\
\hline & Other / unclear \\
\hline \multirow{4}{*}{ - Sampling } & Random \\
\hline & Non-random: a cluster sampling \\
\hline & Non-random: a convenience sampling \\
\hline & Other / unclear \\
\hline \multicolumn{2}{|l|}{ - Country (s) of study } \\
\hline \multicolumn{2}{|l|}{ - Population, age } \\
\hline $\begin{array}{l}\text { - Population, other characteristics (gender, ethnic group, occupational group, health } \\
\text { status, etc.) }\end{array}$ & \\
\hline
\end{tabular}

Determinants and outcomes characteristics

\begin{tabular}{l|l}
\hline \multirow{2}{*}{\begin{tabular}{l|l} 
- At what territorial level are the population characteristics represented? & At the level of large regions only \\
\cline { 2 - 2 } - Territorial units in the study and their number $(\mathrm{n})$ & At the level of large regions and at another level \\
\hline \multirow{2}{*}{$\begin{array}{l}\text { - Are the population characteristics represented by single indicator (s) or complex index } \\
\text { (s) (based on several single indicators)? }\end{array}$} & Single \\
\cline { 2 - 2 } & Multidimensional \\
\cline { 2 - 2 } - List all population characteristics & \\
\hline - List all individual outcomes of interest (alcohol and tobacco consumption) in the study & \\
\hline - List the methods, names of survey questionnaires, etc., by which alcohol and / or \\
tobacco use was assessed
\end{tabular}} \\
\hline \multirow{2}{*}{ - In addition to the outcomes of interest, have any other outcomes been studied? } & Not studied \\
\cline { 2 - 2 } & Studied \\
\hline
\end{tabular}

Statistical analysis

\begin{tabular}{l|l}
\hline \multirow{2}{*}{ - Have multi-level statistical analysis techniquesbeen used (e.g. GLMM, GEE) or not? } & Used \\
\cline { 2 - 2 } & Not used \\
\hline -If so, specify thetechnique(s) & \\
\hline \multirow{2}{*}{ - Have multivariate analyzes been used to adjust for individual variables? } & Used \\
\cline { 2 - 2 } & Not used \\
\hline - If so, list the individual variables for which the adjustment was made & Yes \\
\cline { 2 - 2 } - Have the interactions between individual variables beenanalyzed? & Yes \\
\cline { 2 - 2 } - Have any subgroups been stratified? & No \\
\hline \multicolumn{2}{|c}{ Results of review } \\
\hline - List all the main results obtained, including analysis of interactions, stratification \\
analysis of differences by gender, age, etc.
\end{tabular}
analysis of differences by gender, age, etc.

expressed as odds ratios, relative risk, or other measures of association and their $95 \%$ confidence intervals will be calculated for analysis. Where effect estimates and standard errors are not available, they will be calculated from crude data and $95 \%$ confidence intervals (95\% CIs). When correlation coefficients are used to measure the effect size, effect sizes will be converted into a standard normal metric (using Fisher's r-to-Z transformation) and then a weighted average of these transformed scores will be calculated. In a random effects model, untransformed effect-size estimates will be used to calculate the weighted mean correlation coefficient.

The choice of model (random or fixed effects) and the meta-analysis method will be based on the guidance by Moola et al [19]. Heterogeneity will be assessed statistically using the standard chi-squared and I 2 tests. Subgroup analyses will be conducted where there is sufficient data to investigate. Also, where data permit, 
sensitivity analyses will be conducted by excluding studies of poor methodological quality to assess the robustness of the conclusions. A statistical analysis will be performed using JBI SUMARI. Where statistical pooling is not possible, the findings will be presented in a narrative form, including tables and figures, to aid in data presentation where appropriate.

A funnel plot will be generated within JBI SUMARI to assess publication bias if 10 or more studies are included in a meta-analysis.

\section{Discussion}

This planned review and meta-analysis will systematically examine the available evidence on the effect of characteristics of large national regions on alcohol and tobacco consumption. Collecting and synthesizing information on potential factors that can explain the influence of the area of residence on alcohol and tobacco consumption will identify the courses for future research. The results of the systematic review will provide practitioners with an understanding of the nature and consequences of the impact of the external environment, in its broadest sense, on the formation and prevalence of bad habits. This will be the first systematic review and meta-analysis on this topic.

Potential limitations for the review should be noted. As data will be retrieved using only full-text articles, this review will be based solely on published research. It is suggested that researchers should strive to include unpublished literature in meta-analyses and systematic reviews. However, the inclusion of data from unpublished studies could be the cause of bias [11]. In addition, unpublished studies may be of lower methodological quality than published studies. A study of 60 metaanalyses that included published and unpublished trials found that unpublished trials were less likely to conceal intervention allocation adequately and to blind outcome assessments [9].

The limitation of this review is the inclusion of papers from only English-language and Russian-language databases, which is associated with the desire to study the texts of the discovered papers in depth and a comprehensive examination of all the features of the included studies. At the same time, there is certainly a risk of underestimation of studies published in other languages, which should be taken into account when interpreting the results of the review.

\section{Rewiew status}

The team is currently in the process of literature search and the review is expected to be submitted for publication in November 2021.

\section{Autor contributions}

Maksimov S. A. contributed to conception and design of the study; Maksimov S. A., Shalnova S. A. and Drapkina O. M. wrote the first draft of the manuscript; Tsygankova D. P., Danilchenko Y. V. and Zelenina A. A. wrote sections of the manuscript. All authors contributed to manuscript revision, read, and approved the submitted version. There is no conflict of interest in this project.

\section{Acknowledgments}

We would like to thank Editage (www.editage.com) for English language editing.

\section{Funding}

The study was conducted as part of a state assignment in National Medical Research Center for Therapy and PreventiveMedicine of the Ministry of Healthcare of the Russian Federation. This research received no external funding.

Sergey A. Maksimov - SPIN 4362-1967; ORCID 00000003-0545-2586

Daria P. Tsygankova - SPIN 8064-3000; ORCID 00000001-6136-0518

Yana V. Danilchenko - SPIN 2097-0898; ORCID 00000001-8308-8308

Svetlana A. Shalnova - SPIN 9189-8637; ORCID 00000003-2087-6483

Anastasia A. Zelenina - SPIN 8338-3882; ORCID 00000003-4720-6674

Oksana M. Drapkina - SPIN 4456-1297; ORCID 00000002-4453-8430

\section{References}

1. Agudo A., Bonet C., Travier N., Gonzalez C. A., Vineis P., Bueno-de-Mesquita H. B., et al. Impact of cigarette smoking on cancer risk in the European prospective investigation into cancer and nutrition study. J Clin Oncol. 2012, 30 (36), pp. 4550-4557. DOI: 10.1200/JCO.2011.41.0183

2. Algren M. H., Bak C. K., Berg-Beckhoff G., Andersen P. T. Health-risk behaviour in deprived neighbourhoods compared with non-deprived neighbourhoods: A systematic literature review of quantitative observational studies. PLoS One. 2015, 10 (10), e0139297. DOI: 10.1371/journal. pone. 0139297

3. Arcaya M. C., Tucker-Seeley R. D., Kim R., SchnakeMahl A., So M., Subramanian S. V. Research on neighborhood effects on health in the United States: A systematic review of study characteristics. Soc Sci Med. 2016, 168, pp. 16-29. DOI: 10.1016/j.socscimed.2016.08.047

4. Barlow P., McKee M., Basu S., Stuckler D. The health impact of trade and investment agreements: A quantitative systematic review and network co-citation analysis. Global Health. 2017, 13 (1), p. 13. DOI: 10.1186/s12992-0170240-x

5. Cohen S. A., Greaney M. L., Klassen A. C. A "Swiss paradox" in the United States? Level of spatial aggregation changes the association between income inequality and morbidity for older Americans. Int J Health Geogr. 2019, 18 (1), p. 28. DOI: 10.1186/s12942-019-0192-x

6. Corsi D. J., Subramanian S. V., Chow C. K., McKee M., Chifamba J., Dagenais G., et al. Prospective Urban Rural Epidemiology (PURE) study: Baseline characteristics of the household sample and comparative analyses with national data in 17 countries. Am Heart J. 2013, 166 (4), pp. 636-646. DOI: $10.1016 /$ j.ahj.2013.04.019

7. Day K. Built environmental correlates of physical activity in China: A review. Prev Med Rep. 2016, 3, pp. 303-316. DOI: 10.1016/j.pmedr.2016.03.007

8. Diez Roux A. V. Complex systems thinking and current impasses in health disparities research. Am J Public Health. 2011, 101 (9), pp. 1627-1634.DOI: 10.2105/ AJPH.2011.300149

9. Egger M., Juni P., Bartlett C., Holenstein F., Sterne J. How important are comprehensive literature searches and the 
assessment of trial quality in systematic reviews? Empirical study. Health Technol Assess. 2003, 7 (1), pp. 1-76.

10. Finke I., Behrens G., Weisser L., Brenner H., Jansen L. Socioeconomic differences and lung cancer survival-systematic review and meta-analysis. Front Oncol. 2018, 8, p. 536. DOI: 10.3389/fonc. 2018.00536

11. Higgins J. P. T., Thomas J., Chandler J., Cumpston M., Li T., Page M. J., et al. Cochrane Handbook for Systematic Reviews of Interventions version 6.2 (updated February 2021 ). Cochrane, 2021. Available at: www.training.cochrane. org/handbook

12. Karriker-Jaffe K. J., Roberts S. C. M., Bond J. Income inequality, alcohol use, and alcohol-related problems. Am J Public Health. 2013, 103 (4), pp. 649-656. DOI: 10.2105/ AJPH.2012.300882

13. Kondo N., Sembajwe G., Kawachi I., van Dam R. M., Subramanian S. V., Yamagata Z. Income inequality, mortality, and self rated health: meta-analysis of multilevel studies. $B M J$. 2009, 339, b4471. DOI: 10.1136/bmj.b4471

14. Krieger N. Epidemiology and the web of causation: has anyone seen the spider? Soc Sci Med. 1994, 39 (7), pp. 887-903. DOI: 10.1016/0277-9536(94)90202-x

15. Leal C., Chaix B. The influence of geographic life environments on cardiometabolic risk factors: A systematic review, a methodological assessment and a research agenda. Obes Rev. 2011, 12 (3), pp. 217-230. DOI: 10.1111/j.1467789X.2010.00726.x

16. Liberati A., Altman D. G., Tetzlaff J., Mulrow C., Gøtzsche P. C., Ioannidis J. P., et al. The PRISMA statement for reporting systematic reviews and meta-analyses of studies that evaluate health care interventions: Explanation and elaboration. PLoS Med. 2009, 6 (7), e1000100. DOI: 10.1371/journal.pmed. 1000100

17. Maksimov S. A., Shalnova S. A., Balanova Y. A, Kutsenko V. A., Evstifeeva S. E., Imaeva A. E., et al. What regional living conditions affect individual smoking of adults in Russia. Int J Public Health. 2021, 66, p. 599570. DOI: 10.3389/ijph.2021.599570

18. March D., Susser E. The eco- in eco-epidemiology. Int J Epidemiol. 2006, 35 (6), pp. 1379-1383. DOI: 10.1093/ ije/dyl249

19. Moola S., Munn Z., Sears K., Sfetcu R., Currie M., Lisy K., et al. Conducting systematic reviews of association (etiology): The Joanna Briggs Institute's approach. Int J Evid Based Healthc. 2015, 13 (3), pp. 163-169. DOI: 10.1097/ XEB.0000000000000064

20. Moola S., Munn Z., Tufanaru C., Aromataris E., Sears K., Sfetcu R., et al. Chapter 7: Systematic reviews of etiology and risk. In: Aromataris E, Munn Z, editors. JBI Manual for Evidence Synthesis [internet]. Adelaide: JBI. 2017 [cited 2020 December 27]. Available at: https:// synthesismanual.jbi.global.

21. Munn Z., Aromataris E., Tufanaru C., Stern C., Porritt K., Farrow J., et al. The development of software to support multiple systematic review types: The Joanna Briggs Institute System for the Unified Management, Assessment and Review of Information (JBI SUMARI). Int J Evid Based Healthc. 2019, 17 (1), pp. 36-43. DOI: 10.1097/XEB.0000000000000152

22. Munn Z., Barker T. H., Moola S., Tufanaru C., Stern C., McArthur A., et al. Methodological quality of case series studies: An introduction to the JBI critical appraisal tool. JBI Evid Synth. 2020, 18 (10), pp. 2127-2133. DOI: 10.11124/JBISRIR-D-19-00099

23. Naik Y., Baker P., Ismail S. A., Tillmann T., Bash K., Quantz D., et al. Going upstream - an umbrella review of the macroeconomic determinants of health and health inequalities. BMC Public Health. 2019, 19 (1), p. 1678. DOI: 10.1186/ s12889-019-7895-6

24. O’Donnell M. J., Chin S. L., Rangarajan S., Xavier D., Liu L., Zhang H., et al. Global and regional effects of potentially modifiable risk factors associated with acute stroke in 32 countries (INTERSTROKE): a case-control study. Lancet. 2016, 388 (10046), pp. 761-775. DOI: 10.1016/ S0140-6736(16)30506-2

25. Pruitt S. L., Shim M. J., Mullen P. D., Vernon S. W., Amick B. C. The association of area socioeconomic status and breast, cervical, and colorectal cancer screening: A systematic review. Cancer Epidemiol Biomarkers Prev. 2009, 18 (10), pp. 2579-2599. DOI: 10.1158/1055-9965.EPI-09-0135

26. Quon E. C., McGrath J. J. Province-level income inequality and health outcomes in Canadian adolescents. J Pediatr Psychol. 2015, 40 (2), pp. 251 -261. DOI: 10.1093/ jpepsy/jsu089

27. Sallis J. F., Cervero R. B., Ascher W., Henderson K. A., Kraft M. K., Kerr J. An ecological approach to creating active living communities. Annu Rev of Public Health. 2006, 27, pp. 297-322. DOI: 10.1146/annurev. publhealth.27.021405.102100

28. Shmulewitz D., Stohl M., Keyes K. M., Brown Q., Saha T. D., Hasin D. Effects of state-level tobacco environment on cigarette smoking are stronger among those with individual-level risk factors. Nicotine Tob Res. 2016, 18 (10), pp. 2020-2030. DOI: $10.1093 / \mathrm{ntr} / \mathrm{ntw} 114$

29. Susser M., Susser E. Choosing a future for epidemiology: II. From black box to Chinese boxes and eco-epidemiology. Am J Public Health. 1996, 86 (5), pp. 674-677. DOI: 10.2105/ajph.86.5.674

30. Toms R., Bonney A., Mayne D. J., Feng X., Walsan R. Geographic and area-level socioeconomic variation in cardiometabolic risk factor distribution: A systematic review of the literature. Int J Health Geogr. 2019, 18 (1), p. 1. DOI: 10.1186/s12942-018-0165-5

31. Xuan Z., Blanchette J. G., Nelson T. F., Nguyen T. H., Hadland S. E., Oussayef N. L., et al. Youth drinking in the United States: relationships with alcohol policies and adult drinking. Pediatrics. 2015, 136 (1), pp. 18-27.DOI: 10.1542/ peds.2015-0537

32. Yusuf S., Hawken S., Ounpuu S., Dans T., Avezum A., Lanas F., et al. Effect of potentially modifiable risk factors associated with myocardial infarction in 52 countries (the INTERHEART study): case-control study. Lancet. 2004, 364 (9438), pp. 937-952. DOI: 10.1016/S0140-6736(04)17018-9

\section{Contact details:}

Maksimov Sergey Alekseevich - PhD, Leading Researcher, National Medical Research Center for Therapy and Preventive Medicine, Moscow, Russia

101990, Moscow, Petroverigskiy Pereulok, 10, bld. 3

E-mail: m1979sa@yandex.ru 